\title{
Влияние экзогенных конечных продуктов глубокого гликирования на первичный метаболом культуры Rhizobium leguminosarum
}

\author{
Кузнецова А. ${ }^{1 *}$, Шумилина Ю. ${ }^{1}$, Династия Е. ${ }^{1,2,3}$, Илинг К. ${ }^{4}$, Попова В. ${ }^{1,2}$, Гришина T. ${ }^{1}$, \\ Васко В.А. ${ }^{2}$, Зинц А. ${ }^{4}$, Вестерманн Б. ${ }^{2}$, Фролов А. ${ }^{1,2}$ \\ ${ }^{1}$ Санкт-Петербургский государственный университет, Кафедра Биохимии, Санкт-Петербург, Россия \\ ${ }^{2}$ Институт биохимии растений им. Лейбница, Департамент Биоорганической Химии, Халле, Германия \\ ${ }^{3}$ Институт органического синтеза им. И.Я. Постовского Уральского отделения Российской академии наук, \\ Екатеринбург, Россия \\ ${ }^{4}$ Университет им. Мартина Лютера Галле-Виттенберг, Халле, Германия \\ *e-mail:alena_kyy@mail.ru
}

Ключевые слова: конечные продукты глубокого гликирования (КПГГ), первичные меаболиты, ризобии, Rhizobium leguminosarum

Мотивация и цель: Ризобиальные бактерии - это азотфиксирующие почвенные микроорганизмы, способные образовывать симбиотические ассоциации - клубеньки на корнях бобовых растений. Являясь одним из партнеров симбиоза, они в значительной степени оказывают влияние на урожайность бобовых культур. Показано, что старение и стресс у растений сопровождаются накоплением конечных продуктов глубокого гликирования (КПГГ) [1]. Однако вопрос влияния экзогенных КПГГ на ризобии остается малоизученным. Поэтому, целью данной работы было изучение влияния экзогенных КПГГ, в частности $N^{\delta}$-(5-метил-4-имидазолон-2-ил) орнитина (MGН1), на метаболом ризобий.

Mетоды и алгоритмы: Культура Rhizobium leguminosarum bv viciae RCAM1026 была проинкубирована с 25 мкмоль/л MG-H1 в течение 0,5 и 18 часов. Из ризобий были выделены первичные метаболиты методом водно-метанольной экстракции. Анализ первичных метаболитов проводился при помощи газовой хроматорафии, сопряженной с квадрупольной массспектрометрией с электронным ударом (EI-Q-MS). Поиск и идентификация метаболитов были проведены с использованием программных пакетов AMDIS, MSDIAL и Xcalibur 3.0, а также программного обеспечения MetaboAnalyst.

Результаты: В ходе анализа экспериментальных и контрольных образцов $R$. leguminosarum было обнаружено 62 первичных метаболитов. При этом, добавление MG-H1 в культуральную среду способствовало повышению уровня метаболитов, вовлеченных в энергетические процессы клетки. Заключение: Добавление MG-H1 в питательную среду вызвало изменения в первичном метаболомеризобий, выражающиеся в усилении процессов энергетического обмена. Однако механизмы, лежащие в их основе, еще предстоит выяснить.

Благодарности: Работа выполнена при поддержке Российского фонда фундаментальных исследований (проект 18-016-00190).

Список литературы

1. Paudel G. et al. Osmotic stress isaccompanied by protein glycation in Arabidopsis thaliana. J Exp Bot. 2016;67:62836295. 